\title{
Towards another dusty summit
}

The British government seems reconciled to yet another European meeting when it is in a minority of one, but the whole of Europe needs better preparation for the grand schemes now under way.

BRITAIN is likely again to be the odd man out at this weekend's meeting of the European Communities (EC) in Luxembourg, but for no good reason. It is a curious, but explicable, situation, turning on the exact meaning of the word 'federal'. A year ago, the then British government under Mrs Margaret Thatcher was forced (some say "ambushed") into participation in two conferences (on political and monetary union). The objective is to amend and strengthen the Treaty of Rome, upon which the continuation of the European enterprise depends. Now there has appeared (not for general circulation) the draft of a document whose preamble contains the word the British distrust. The fear has taken root that the Prime Minister, Mr John Major, cannot assent to such a piece of paper without further alienating those among his own supporters who nurse the deepest suspicions of the mainland, but cannot refrain from signing it without risking further derision and contumely from the other eleven members.

The weekend's row, if it materializes, will be symbolic rather than real. There is nothing intrinsic to the use of the word federal that need so offend Britain's Eurosceptics. The dictionary meanings of the word range from one that covers the EC as it is at present (all of whose members have ratified the Treaty of Rome) to one that described the United States of America two centuries ago - states compacted to act externally in concert which are nevertheless internally independent - but which is an insufficient description now. In the real world, Major could agree to the offending piece of paper while emphasizing both the conditions that must be satisfied and the time that must pass before a true federation will be possible. If reason were all that mattered, he could prudently calculate that the chauvinistic inclinations of many other member states will provide ample breathing-space.

Sadly, the issue that has now been sharpened is not entirely a matter of reason. Britain has never been a full-throated member of the EC. It stood apart from the negotiation of the Treaty of Rome in the 1950s, responded to the rejection of its membership application in 1963 by setting out to create the European Free Trade Area, but abandoned that when, in 1970 , it seemed as if membership would be preferable and possible. For much of that early period, British ambivalence had its roots in hankerings after stronger Commonwealth and/or Transatlantic relationships - hankerings themselves undermined by other ambivalences. Since the early 1970s, there has never been a British government so sure of its own party's European convictions that it could warmly advocate the benefits and the opportunities of being a part of Europe proper, not just an off-shore island. The result is that Britain has been obdurately, even aggressively, lukewarm about European membership. Major cannot complain that the Luxembourg meeting promises to be yet another occasion when the other members seek some more positive sign.

The trouble is mostly political. The Conservative Party's divisions on European policy have been sharpened by the departure of Mrs Thatcher after a row on precisely this issue after Sir Geoffrey Howe's resignation last year. Major has been hoping for peace and quiet while the negotiations are under way, promising that it will by then be for the House of Commons to decide. But that is clearly a high-risk strategy. Would the Eurosceptics toe the line any more willingly then, closer to the deadline for a general election, when many of them would have even less to lose by opposition?

The pity is that the party division probably does not represent a similar difference of opinion within Britain as a whole. And politicians are probably as bewildered as their electors by the heady European concepts now in the air - that of a single currency (on which even Germany has now cooled) and of the "economic convergence" that is its pre-condition, for example. And what exactly is meant by a federal Europe when there is no agreement yet on the technicalities of defence, let alone on broad questions of foreign policy? What Britain and the rest of Europe need is plain speaking about all these issues. British politicians may have an immediate interest in keeping quiet on them, but those elsewhere have not been all that open on the same issues. They should more openly speak what is in their minds.

\section{Early bird born late}

A pre-Archaeopteryx animal with wings will have to make its way with difficulty into the world.

THE timing of the discovery of Archaeopteryx in 1861 was impeccable, just when Darwin's Origin needed support in the eyes of critics. But that is not how it seemed to Richard Owen, the anatomist who remained in ironic opposition to Darwin's views despite his formal description of Archaeopteryx ("ancient wing") in the Philosophical Transactions of the Royal Society. From the outset, Archaeopteryx was not just the missing link between reptiles and birds, but a source of controversy, the subject of allegations of victorian scientific fraud and the very emblem of evolutionary transforma- 